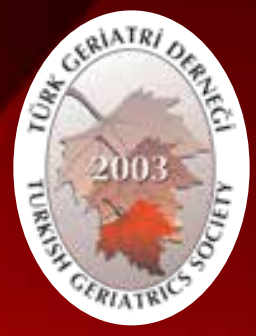

Turkish Journal of Geriatrics DOI: 10.31086/tigeri.2019.92 2019;22 (2):191-196

CORRESPONDANCE

Candan MANSUROĞLU

Ankara Numune Research and Education Hospital, Cardiology Department, Ankara, Turkey.

Phone: +903125084776

e-mail: camansuroglu@hotmail.com.tr

Received: 14/03/2019

Accepted: 28/05/2019

Ankara Numune Research and Education Hospital, Cardiology Department, Ankara Turkey.

\section{IMPACT OF SPINAL AND GENERAL ANESTHESIA ON HS-TROPONIN IN GERIATRIC PATIENTS}

\section{Abstract}

Introduction: We compared the myocardial injury risk of selective spinal anesthesia and general anesthesia with using peri operative plasma high sensitive- cardiac troponins in geriatric noncardiac surgery patients.

Materials and Method: We planned the study as prospective, randomized and double blinded. The study group was consisted of American Society of Anesthesiologist score I- II over 65 years old 46 preoperative non- cardiac surgery patients which randomly separated into the general or selective spinal anesthesia groups. Demographic characteristics of the groups were nearly the same. Anesthesia was performed via injection of bupivacaine $5 \mathrm{mg}$ in Lumbar 4-5 intervertebral space in selective spinal anesthesia group, and propofol and remifentanil for anesthesia induction and then desflurane inhalation with laryngeal mask for anesthesia maintenance in general anesthesia group. Patients' 12 lead electrocardiograms and high sensitive-troponins were taken on the day of operation and postoperative day 1,2 and 3 .

Results: In this study any cardiac complication was observed and high sensitive- Troponin T levels were at the normal range of mean of $13.90 \pm 4,24 \mathrm{ng} /(95 \% \mathrm{Cl}, 8.90-18.20 ; \mathrm{p}=0.43)$. High sensitive-Troponin T was slightly increased the near significant of a mean $19.34 \pm 3.2 \mathrm{ng} / \mathrm{L}(95 \% \mathrm{Cl}$, 15.43- 23.52; $p=0.05$ ) in spinal anesthesia group than general anesthesia on postoperative third day.

Conclusion: Any distinct difference in myocardial injury was not observed between low risk non cardiac operations in the elderly with selective spinal anesthesia and with general anesthesia methods in our study. However, the third day increase in high sensitive-Troponin in selective spinal anesthesia group needs larger studies with longer follow- up in moderate to high risk patients in clinical practice usage.

Keywords: Aged; Anesthesia; Surgical Procedures, Operative; Postoperative complications; Troponin

\section{ARAŞTIRMA}

\section{GERIATRI YAŞ GRUBU HASTALARDA SPINAL VE GENEL ANESTEZININ HS-TROPONINE ETKisi}

$\ddot{O}_{z}$

Giriş: Geriatrik hastalarda non- kardiyak cerrahi işlemlerde selektif spinal anestezi ile genel anestezi metodlarının kardiyak hasar oluşturma riskini perioperatif plazma high sensitive- troponin Tile karşılaştırdık.

Gereç ve Yöntem: Çalışmayı prospektif, randomize ve çift- kör olarak planladık. Çalışma grubu Amerikan Anestezi Derneği skorul-II olan 65 yaş üzeri, rastgele selektif spinal anestezi ya da genel anestezi gruplarına ayrıımıs 46 alt ekstremite ameliyatı hastasından oluşmuştur. Her iki grubun demografik özellikleri benzerdi.Selektif spinal anestezi grubunda anestezi, Lumbar 4-5 spinal seviyeye $5 \mathrm{mg}$ bupivakain enjeksiyonu ile genel anestezi grubunda ise propofol ve remifentanil ile indüksiyon sonrası idame laringeal maske ile desfluran inhalasyonu ile sağlandı. Operasyon gününde ve postoperatif 1, 2 ve 3 . günlerde, 12- derivasyon elektrokardiyogramları çekildi ve plazmahigh sensitive- troponin T çalışıldı.

Bulgular: Hastalarda kardiyak komplikasyon görülmedi ve high sensitive- troponin seviyeleri ortalama13.90 $\pm 4.24 \mathrm{ng} / \mathrm{L}(\% 95 \mathrm{GA}, 8.90-18.20 ; \mathrm{p}=0.43)$ normal sınırlarda idi. Selektif spinal anestez grubunun 3. günde high sensitive- troponin seviyeleri ortalama 19.34 $\pm 3.2 \mathrm{ng} / \mathrm{L}$ (\%95 GA, 15. 43- 23, $52 ; \mathrm{p}=0.05$ ) ve anlamlıya yakın yüksekti.

Sonuç: Çalışma sonuçlarımızda, düşük risk grubunda ki yaşlı hastaların alt ekstremite ameliyatlarında selektif spinal ve genel anestezi uygulamaları arasında kardiyak hasar açısından belirgin bir fark görülmedi. Ancak, selektif spinal anestezi grubunda 3. günde ki yükselmenin klinik pratikteki önemini anlamak için, orta-yüksek ve yüksek riskli hasta gruplarında, daha büyük ve uzun dönem takipli çalışmalara intiyaç olduğu sonucuna vardık.

Anahtar sözcükler: Yaşli; Anestezi; Kalp-dışı cerrahi; Postoperatif komplikasyon; Troponin 


\section{INTRODUCTION}

Aged people is increasing with the result of better living conditions and improved technological development in our country as in the world. According to World Health Organization (WHO), 1.2 million people will be 65 years old and over in 2025, and this number will reach 2 million in 2050 $(1,2)$. Nearly half million patients undergo a major surgery annually worldwide and postoperative complications are becoming an increasing problem in aged people (3). The 30 - day mortality is $2 \%$ in moderate to high cardiac risk patients and $5 \%$ in high cardiac risk patients (4-6). Mortality occurs mostly frompostoperative cardiopulmonary complications especially from acute myocardial infarction(AMI) which sometimes may be silent or occur without a symptom in sedated and anesthetized patient $(7,8)$. One million patients die from perioperative AMl yearly (9). Nagele et al found that preoperative cardiac troponins can be a specific, sensitive and rapid biomarker for categorising the risk for $\mathrm{AMI}$ and mortality in preoperative patients (10). Recent studies denoted that even a slight increase troponins were associated with myocardial injury and increased risk of cardiac complications (1113). High sensitive- cardiac troponins(hs- Tc) assays which were introduced to detect the low level of troponins and are positive for myocardial ischemia even other cardiac enzymes are normal (14-16). The studies investigating safer anesthetic method in aged patients showed different results any valid opinion is not present. In this study, we aimed to detect the myocardial ischemia via measuring perioperative hs-cT's to find out the safer anesthetic method in geriatric patients undergoing a non cardiac operation.

\section{MATERIALS AND METHOD}

\section{Study population}

Following getting our trial permission from our hospital local ethics and trial committee and collection of informed consent, 46 American
Society of Anesthesiologist score (ASA) I-II patients over 65 years of age who were scheduled to undergo elective orthopedic lower limb surgery and randomized in two groups: Group S ( $n=23)$ and Group $G(n=23)$ undergoing surgery with selective spinal or general anesthesia. The trial number was 13/ 2017 and designed as prospective, randomized, double-blind study and conducted between May and October 2018 in at our hospital orthopedics clinics. The study were performed by the personal unaware of clinical outcomes. Anesthesia doctors and technicians were collected the blood samples but didn't know the analysis groups. The technicians, physicians and analysts who performed the tests were not informed about the study. Patient characteristics were listed in Table 1. A Mallampati score $>2$, long QT syndrome (acquired or congenital), cardiovascular disease, chronic obstructive lung disease, diabetes mellitus, chronic alcohol and drug using patients were excluded from the study. Hemodynamic monitoring datas that are consist of peripheral oxygen saturation $\left(\mathrm{SpO}_{2}\right)$, heart rate $(\mathrm{HR})$ and mean arterial pressure (MAP) were evaluated preoperative section and patients didn't get any premedication. Propofol and remifentanil were used to get the anesthesia induction and endotracheal intubation was performed after neuromuscular block with 0 . $1 \mathrm{mg} \mathrm{kg}-1$ rocuronium in Group G. Maintenance of anesthesia was ensured with $50 \% \mathrm{~N}_{2} \mathrm{O} / \mathrm{O}_{2}$ and 2- 2. $5 \%$ sevoflurane inhalation. When the patients were in the sitting position $15 \mathrm{mg} 0.5 \%$ hyperbaric bupivacaine were given to the L4-L5 space in the midline to get the spinal anesthesia in Group S. The pinprick test and the Bromage scale were used for sensory and motor block. Surgery was started when the T10 level sensory block was reached.

\section{Biomarker assays}

Blood samples were collected in serum separation tubes and centrifuged and 12lead electrocardiogram (ECC)'s were taken on preoperative (baseline) and the mornings of postoperative days 1,2 , and 3 . Samples were 
Table 1. Descriptive statistics of predictors.

\begin{tabular}{|c|c|c|c|}
\hline Study sample $(n=46)$ & Group G $(n=23)$ & Group S $(n=23)$ & $\mathrm{p}$ \\
\hline Mean age, y (sd) & $74.2 \pm 2.4$ & $76 \pm 4.5$ & 0.35 \\
\hline Female sex, n (\%) & $14(60.8)$ & $16(69.5)$ & 0.23 \\
\hline Smoking history, n (\%) & $8(34.7)$ & $6(27.0)$ & 0.14 \\
\hline Diabetes, n(\%) & $10(23.2)$ & $7(20.7)$ & 0.19 \\
\hline Hypertension, n(\%) & $10(23.2)$ & $11(25.5)$ & 0.32 \\
\hline Hypercholesterolemia, n(\%) & $7(30.4)$ & $9(39.1)$ & 0.45 \\
\hline Creatinine, $\mathrm{mg} / \mathrm{dL}$, mean $\pm \mathrm{sd}$ & $1.0 \pm 0.4$ & $1.1 \pm 0.8$ & 0.45 \\
\hline Coronary artery disease, $\mathrm{n}(\%)$ & - & - & - \\
\hline Atrial fibrillation, n(\%) & - & - & - \\
\hline $\begin{array}{l}\text { Lee's revised cardiac risk index } \\
1 \\
2 \\
3 \\
4\end{array}$ & $\begin{array}{r}14(60.6) \\
9(39.1) \\
- \\
-\end{array}$ & $\begin{array}{r}17(73.9) \\
6(26.0) \\
- \\
-\end{array}$ & $\begin{array}{r}0.42 \\
0.39 \\
- \\
-\end{array}$ \\
\hline $\begin{array}{l}\text { Medications } \\
\text { Aspirin, n (\%) } \\
\text { Clopidogrel, n (\%) } \\
\text { Warfarin, n (\%) } \\
\text { B- blocker, n (\%) } \\
\text { Statin, n (\%) } \\
\text { ACE inhibitors, n (\%) } \\
\text { Calcium-channel blocker, n (\%) } \\
\text { ARB, n (\%) } \\
\text { Nitrates, n (\%) } \\
\text { Diuretics, n (\%) }\end{array}$ & $\begin{array}{r}5(21.7) \\
- \\
- \\
1(0.43) \\
- \\
3(13.04) \\
5(21.7) \\
1(4.3) \\
- \\
-\end{array}$ & $\begin{array}{r}7(30.4) \\
- \\
- \\
0(9.3) \\
- \\
4(17.39) \\
4(17.9) \\
2(8.6) \\
- \\
-\end{array}$ & $\begin{array}{r}0.35 \\
- \\
- \\
0.78 \\
- \\
0,17 \\
0.56 \\
0.67 \\
- \\
-\end{array}$ \\
\hline
\end{tabular}

separated into aliquots and were frozen $-80^{\circ} \mathrm{C}$ until they were assayed. Biomarker measurements were carried out in batches and no more than 2 freeze thaw cycles. Hs-cTnT concentrations (presented as nanograms per liter equal to picograms per milliliter) were measured by on Cobas e601 autoanalyzer (Roche Diagnostics, Germany). Measurable Ranges were 3- $10000 \mathrm{ng} / \mathrm{L}$ or $\mathrm{pg} / \mathrm{mL}$ (limit of detection 5 $n g / L)$.

\section{Statistical analysis}

SPSS soft ware (Version 18. 0, SPSS Inc. Chicago, IL, USA) were used for statistical analysis. Variables was analyzed using the KolmogorovSmirnov test. Categorical variables were presented as percentages and parametric variables were presented as mean \pm standard deviation. Nonparametric variables were expressed as median (minimum-maximum). The normally distributed 
Table 2. Hs- cTnT levels in ng/L \pm sd before surgery and on postoperative day 1,2 and 3 .

\begin{tabular}{|l|r|r|r|}
\hline Hs- cTnT,ng/ LI sd & Group G (n=23) & Group S (n=23) & p \\
\hline Before surgery, ng/L & $15.90 \pm 4.24$ & $12.42 \pm 5.01$ & 0.27 \\
\hline Postoperative day 1, ng/L & $13.25 \pm 1.941$ & $10.89 \pm 1.19$ & 0.45 \\
\hline Postoperative day 2, ng/L & $12.56 \pm 2.59$ & $11.32 \pm 4.04$ & 0.40 \\
\hline Postoperative day 3, ng/L & $13.09 \pm 4.32$ & $19.34 \pm 3.2$ & 0.05 \\
\hline
\end{tabular}

numeric variables were analyzed with the Student's t-test, and non-normally distributed variables were evaluated by the Mann-Whitney $U$ test variance analysis. The categorical variables compared with Chi-square test. $\mathrm{P}$ value $<0.05$ was accepted as statistically significant.

\section{RESULTS}

Before and after surgery, all patients had a level of $>5 \mathrm{ng} / \mathrm{L}$ hs-cTnT concentration. Before operation Group $G$ had a mean of $15.90 \pm 4.24 \mathrm{ng} / \mathrm{L}(95 \%$ $\mathrm{Cl}, 7,43-18,52)$ and Group S had 12, 42 $\pm 5,01$ $\mathrm{ng} / \mathrm{L}$ hs-cTnT(95\% Cl, 8.13-19.27). ( $p=0.090)$. On postoperative day 1, Group $\mathrm{G}$ patients had a mean hs-cTnT 13.25 $\pm 1.941 \mathrm{ng} / \mathrm{L}(95 \% \mathrm{Cl}, 10.43-18.22)$ and Group S patients had a hs-cTnT 10, 89 \pm 1.19 $\mathrm{ng} / \mathrm{L} \quad(95 \% \quad \mathrm{Cl}, \quad 7.83-19.429 . \quad(p=0.45) \quad$ On postoperative second and third days Group $\mathrm{G}$ had a mean $12.56 \pm 2.59 \mathrm{ng} / \mathrm{L}(95 \% \mathrm{Cl}, 5.83-21.22)$ and $13.09 \pm 4.32 \mathrm{ng} / \mathrm{L}(95 \% \mathrm{Cl}, 11.37-23.12)$, and Group $\mathrm{S}$ had mean $11.32 \pm 4.04 \mathrm{ng} / \mathrm{L}(95 \% \mathrm{Cl}, 9.63-19.52)$ and $19.34 \pm 3.2 \mathrm{ng} / \mathrm{L}(95 \% \mathrm{Cl}, 17.43-25.52 ; \mathrm{p}=0.05)$, $(p=0.40$ and 0.05$)$ respectively. The distribution of these values are shown in Table 2.

We didn't observe any cardiac complain and complication during the postoperative days. All the patients had a detectable hs-cTnT concentration before and after surgery. In Group S, we detected a near significant increase in hs- CTnT on postoperative third day and but patients didn't have any cardiac complication. As this finding is well consentient with other studies we think it needs attention to study on.

\section{DISCUSSION}

Nearly 50 million/year patients undergoing noncardiac operations is aged and it is likely that the number will double within years. Operations were done in an expense of cardiac mortality and morbidity, longer hospitalizations and increased cost, etc. About one million patients suffer from fatal and nonfatal perioperative cardiovascular complications annually (17). Ischemic events may occur due to postoperative pain, decreased capacity of $\mathrm{O}_{2}$ carrying, acute reduction of cardiac output or blood pressure, intraoperative and postoperative bleeding, increased metabolic response to increased body temperature and shivering in operations. Especially in SSA myocardial tissue is more prone to ischemic events because of adrenergic hyperactivity and poor pain control. A large proportion of perioperative myocardial ischemia goes silent and undiagnosed and is left without adequate therapy. To prevent these ischemic events guidelines recommend a good preoperative cardiac risk assessment and propose the use of volatile anesthetics as beneficial although there is not enough evidence in high risk patients undergoing noncardiac surgery (class Ila 
recommendation) (18). A systematic review failed to retrieve studies and a small trial published in the meantime did not detect any protective effect of volatile anesthetics on cardiovascular end points in noncardiac surgical patients. In addition the number of studies evaluating effects of spinal anesthesia are scarce. One of these studies compared selective spinal anesthesia with general anesthesia techniques and did not find any significant difference regarding arrhythmia and hemodynamic parameters (19). Another study assessed the effects of anesthesia techniques on myocardial ischemia and reported that anesthesia techniques did not affect serum CK-MB and Troponin I levels and ST segment levels on holter ECG monitorization in elderly patients undergoing urological operations (20). A few studies showed that perioperative cardiac Troponin is more effective than ECG, echocardiography, and other cardiac enzymes in diagnosing myocardial ischemia. HscTn are more sensitive to myocardial injury than the other enzymes, even a small amount of myocardial damage can be detected with them.

We hypothesized to detect the ischemic event with studying the hs- $\mathrm{Tn}^{\prime} \mathrm{s}$ and expose undiagnosed cardiac complications. To our best knowladge, this is the first study comparing cardiac complications of spinal and general anesthetic methods with

\section{REFERENCES}

1. Cilingiroglu N, Demirel S. Aging and ageism. Turkish Journal of Geriatrics 2004;7(4):225-30. (in Turkish).

2. Ozdemir L, Akdemir N, Akyar I. Elderly evaluation form developed for nurses and geriatric problems. Turkish Journal of Geriatrics 2005;8(2):94-100. (in Turkish).

3. Weiser TG, Regenbogen SE, Thompson KD, et al. An estimation of the global volume of surgery: a modelling strategy based on available data. Lancet 2008;372(9633):13944.(PMID:18582931).

4. Lindenauer PK, Pekow P, Wang K, et al. Perioperative beta-blocker therapy and mortality after major noncardiac surgery. N Eng J Med 2005;353(4):349-61. (PMID:16049209). studying hs- cTnTin the literature. In the present study we didn't observed any elevated enzyme level and any ischemic event. This can be due to that our study group consisted of low risk patients and were treated with low risk operations. High risk patients and urgent operations were excluded from our study group according to our study protocol. Because most operations are done in urgent terms in the elderly, low risk patient population is one of the limitation of our study. Second limitation is that data during hospitalization and follow up period is absent. Although the near significant increase in cardiac enzyme level in SSA group correlates with guidelines recommendations we couldn't explain this because our group was small and long term follow up data were absent.

In conclusion, our study showed that elective low risk surgical operations in aged patients are quite safe in our country. Our finding make us to think SSA can be hazardous for myocardial tissue in the elderly patients. We need further confirmatory studies in deciding the safer anesthetic method in the geriatric population.

\section{Conflict of interest}

The authors have no financial disclosures to declare, no conflicts of interest to report, and no commercial or proprietary interest. There was no funding.

5. Wu WC, Schifftner TL, Henderson WG, et al. Preoperative hematocrit levels and postoperative outcomes in older patients undergoing noncardiac surgery. JAMA 2007;297(22):2481-88. (PMID:17565082).

6. Lee TH, Marcantonio ER, Mangione CM, et al. Derivation and prospective validation of a simple index for prediction of cardiac risk of major noncardiac surgery. Circulation 1999;100(10):1043-49. (PMID:10477528).

7. Fleisher LA, Eagle KA, Shaffer T, et al. Perioperativeand long-term mortality rates after major vascular surgery: the relationship to preoperative testing in the medicare population. Anesth Analg 1999;89(49):84955. (PMID:21821518). 
8. Landesberg G, Beatie WS, Mossari M, et al. Perioperative myocardial infarction. Circulation 2009;119(22):2936-44. (PMID:19506125).

9. Devereaux PJ, Xavier D, Pague J, et al. Characteristics and short- term prognosis of perioperative myocardial infarction in patients undergoing noncardiac surgery: A cohort study. Ann Intern Med 2011;154(8):523-28. (PMID:21502650).

10. Nagele P, Rao IK, Penta M, et al. Postoperative myocardial injury after major head and neck cancer surgery. Head Neck 2011;33(8):1085-91. (PMID:20886662).

11. Nagele P, Brown F, Gage BF, et al. High- sensitivity cardiac troponin $\mathrm{T}$ in prediction and diagnosis of myocardial infarction and long- term mortality after noncardiac surgery. Am Heart J 2013;166(2):325-32. (PIMID:23895816).

12. Landesberg G, Shats V, Akopnik I, et al. Association of cardiac troponin, CK- MB, and postoperative myocardial ischaemia with long- term survival after major vascular surgery. J Am Coll Cardiol 2003;42(9):1547-54. (PMID:14607436).

13. Levy M, Hells- Andell D, Hiralal R, et al. Prognostic value of troponin and creatine kinase muscle and brain isoenzyme measurement after noncardiac surgery: a systematic review and meta- analysis. Anesthesiology 2011;114(4):796-806. (PMID:22804867).

14. Ndrepepa G, Braun S, Mehilli J, ,et al. Prognostic value of sensitive troponin $T$ in patients with stable and unstable angina and undetectable conventional troponin. Am Heart 2011;16(1):68-75. (PMID:21167336)
15. Jaffe AS: The 10 commandments of troponin, with special reference to high sensitivity assays. Heart 2011;97(11):940-46. (PMID:21558070).

16. Thygesen K. Mair J, Giannitsis E, et al. How to use highsensitivity cardiac troponins in acute cardiac care. Eur Heart J 2012; 33 (18): 2252-57. (PIMID:22723599).

17. Devereaux PJ, Goldman L, Cook DJ, et al. Perioperative cardiac events in patients undergoing noncardiac surgery: A review of the magnitude of the problem, the pathophysiology of the events and methods to estimate and communicate risk. CMAJ 2005;173(6):627-34. (PMID:16157727).

18. Eagle KA, Berger PB, Calkins $H$, et al. ACC/AHA guideline update for perioperative cardiovascular evaluation for noncardiac surgery. A report of the American College of Cardiology/American Heart Association Task Force on Practice Guidelines (committee to update the 1996 guidelines on perioperative cardiovascular evaluation for noncardiac surgery). Circulation 2002;105(10):1257-67. (PMID:11823097).

19. Lurati Buse GA, Schumacher P, Seeberger E, et al. Randomized comparison of sevoflurane versus propofol to reduce perioperative myocardial ischemia in patients undergoing noncardiac surgery. Circulation 2012;126 (23): 2696-704. (PMID:23136158).

20. Ornek E, Ornek D, Alkent ZP, et al. The effects of volatile induction and maintenance of anesthesia and selective spinal anesthesia on QT interval, QT dispersion, and arrhythmia incidence. Clinics 2010 Jun;65 (8):763-67. (PMID:20835552). 